\title{
Sexual Hormones in Human Skin
}

\author{
Authors \\ C. C. Zouboulis ${ }^{1,2}$, W.-C. Chen ${ }^{3}$, M. J. Thornton ${ }^{4}$, K. Qin ${ }^{5}$, R. Rosenfield ${ }^{5,6}$ \\ Affiliations \\ Affiliation addresses are listed at the end of the article
}

\begin{abstract}
Key words
androgens

- estrogens

progestins

human skin

acne
\end{abstract}

received 23.11.2006

accepted 28.11.2006

Bibiliography

DOI 10.1055/s-2007-961807

Horm Metab Res 2007;

39: 85-95

(c) Georg Thieme Verlag KG

Stuttgart · New York ·

ISSN 0018-5043

Correspondence

C. C. Zouboulis

Departments of Dermato-

logy and Immunology · Dessau

Medical Center - Auenweg

38. 06847 Dessau $\cdot$ Germany

Tel.: +49/340/5014000

Fax: +49/340/5014025

christos.zouboulis@klinikum-

dessau.de

\section{Abstract}

$\nabla$

The skin locally synthesizes significant amounts of sexual hormones with intracrine or paracrine actions. The local level of each sexual steroid depends upon the expression of each of the androgen- and estrogen-synthesizing enzymes in each cell type, with sebaceous glands and sweat glands being the major contributors. Sebocytes express very little of the key enzyme, cytochrome P450c17, necessary for synthesis of the androgenic prohormones dehydroepiandrosterone and androstenedione, however, these prohormones can be converted by sebocytes and sweat glands, and probably also by dermal papilla cells, into more potent androgens like testosterone and dihydrotestosterone. Five major enzymes are involved in the activation and deactivation of androgens in skin. Androgens affect several functions of human skin, such as sebaceous gland growth and differentiation, hair growth, epidermal barrier homeostasis and wound healing. Their effects are mediated by binding to the nuclear androgen receptor. Changes of isoenzyme and/or androgen receptor levels may have important implications in

\section{Introduction}

\section{$\nabla$}

Several functions of the human skin appear strongly dependent on biologically active sexual hormones, namely androgens, estrogens, and progestins. Their effect is mediated by binding to nuclear receptors, and lack of functional receptors prevents the action of sexual hormones on the skin [1]. The effects of sexual hormones can differ from cell type to cell type and among cells of different locations [2]. Androgen effects on the pilosebaceous unit are best known and best characterized. Nevertheless there is considerable variability in the response of the pilosebaceous the development of hyperandrogenism and the associated skin diseases such as acne, seborrhoea, hirsutism and androgenetic alopecia. On the other hand, estrogens have been implicated in skin aging, pigmentation, hair growth, sebum production and skin cancer. Estrogens exert their actions through intracellular receptors or via cell surface receptors, which activate specific second messenger signaling pathways. Recent studies suggest specific site-related distribution of $\operatorname{ER} \alpha$ and $\operatorname{ER} \beta$ in human skin. In contrast, progestins play no role in the pathogenesis of skin disorders. However, they play a major role in the treatment of hirsutism and acne vulgaris, where they are prescribed as components of estrogenprogestin combination pills and as anti-androgens. These combinations enhance gonadotropin suppression of ovarian androgen production. Estrogen-progestin treatment can reduce the need for shaving by half and arrest progression of hirsutism of various etiologies, but do not necessarily reverse it. However, they reliably reduce acne. Cyproterone acetate and spironolactone are similarly effective as anti-androgens in reducing hirsutism, although there is wide variability in individual responses.

unit to androgens that is not yet completely understood [3].

\section{Androgens and skin \\ $\nabla$}

\section{Androgens relevant to the skin}

Among the circulating androgens, dehydroepiandrosterone (DHEA) and DHEA sulfate (DHEA-S) are predominantly produced in the adrenal cortex. Androstenedione is produced approximately equally by the adrenal cortex and the ovaries, and somewhat less by the testes [4]. These are weak prohormones that act only after conversion 
to the more potent androgens, testosterone and $5 \alpha$-dihydrotestosterone (DHT). Testosterone is mainly secreted by the testes in males beginning at puberty; in reproductive-age females it arises almost equally from the ovary and adrenal cortex by a combination of secretion and conversion of androstenedione in peripheral organs. DHT is mainly synthesized in peripheral organs, including skin, in both genders.

Testosterone, particularly free testosterone, is the major circulating androgen because of its concentration and potency [3]. The less potent DHEA-S is the androgen with by far the highest serum concentration in both sexes and is related to sebum production prepubertally [5] and to cystic acne in adults [6]. Androstenedione and DHEA have also been shown to stimulate sebum secretion in humans [7]. Male levels of testosterone stimulate full axillary and pubic hair growth, but in the absence of DHT formation do not suffice to stimulate male beard growth and scalp hair recession [8].

\section{The androgen receptor and skin}

Testosterone and DHT act through a single nuclear receptor, the androgen receptor (AR), with DHT being the more active ligand [9]. AR is an X-chromosome-encoded, ligand-activated, intracellular transcription factor that belongs to the steroid/nuclear receptor superfamily $[2,10]$. Like all nuclear receptors, AR is a soluble molecule with a proclivity for employing transcriptional regulation as a means of promoting its biological effects. In common with other steroid receptors, AR is compartmentalized in the cytoplasm, where it exists in polymeric complexes that include the heat shock proteins hsp 90, hsp 70, and hsp 56. Association of androgens with AR results in dissociation of the heat shock proteins. This in turn exposes a nuclear translocation signal previously buried in the receptor structure and initiates transport of the ligand-receptor complex to the nucleus. There, AR occupies androgen response elements in the promoter regions of androgen-regulated genes to initiate the signaling cascade.

AR is present in epidermal and follicular keratinocytes, sebocytes, sweat gland cells, dermal papilla cells, dermal fibroblasts, endothelial cells, and genital melanocytes $[11,12]$. It is stabilized by ligand binding and is up-regulated in genital skin fibroblasts and sebocytes $[13,14]$.

Polymorphisms that confer enhanced receptor activity have been variably associated with the androgen-dependent skin disorders. Studies of CAG trinucleotide repeats have shown them to have been inconsistently related to hirsutism $[9,15]$. Failure to account for possible skewed X-inactivation of the affected alleles, for which there are likewise conflicting data, contributes to some of the disparities. A recent linkage study has reported that genetic variability in a shorter GGN repeat of the AR gene, which confers a higher gene effect, has an etiological fraction of 0.46 for early-onset familial male-pattern baldness, confirming an earlier study [16]. Thus, this may prove to be a more clear-cut determinant of sensitivity to androgen than the CAG repeat.

\section{Androgen metabolism and its transcriptional regulation} in the skin

The skin can be regarded as a peripheral organ that locally synthesizes significant amounts of androgens with intracrine or paracrine actions $[3,11]$. Having recognized the key effects of biologically active androgens on skin, their local synthesis and degradation have gained special interest. The local level of each sex steroid depends upon the expression of each of the androgen- and estrogen-synthesizing enzymes in each cell type, with sebaceous glands and sweat glands being the major contributors $[9,17]$.

The skin, especially sebocytes, is capable of synthesizing cholesterol, which is utilized in cell membranes, formation of the epidermal barrier and sebum; however, sebocytes express very little of the key enzyme, cytochrome P450c17, necessary for synthesis of the androgenic prohormones DHEA and androstenedione [18]. However, DHEA and androstenedione, and possibly DHEA-S, can be converted by sebocytes and sweat glands, and probably also by dermal papilla cells, into more potent androgens like testosterone and DHT [2]. Five major enzymes are involved in the activation and deactivation of androgens in skin [19]. In a first step, steroid sulfatase hydrolyzes DHEA-S to DHEA in skin [20]. The sebaceous gland has been suggested to carry out this reaction since strong steroid sulfatase immunoreactivity was found in acne skin, primarily associated with the monocytes infiltrating the lesions [21], but further evidence is required to corroborate this preliminary report. This enzyme activity has also been detected in the dermal papillae of human terminal hair follicles [22]. Subsequently, 3 $\beta$-hydroxysteroid dehydrogenase $/ \Delta^{5-4}$-isomerase ( $3 \beta$-HSD) converts DHEA to androstenedione. Two isoforms of this enzyme have been described. Human skin seems to express exclusively the type 1 isoform. Several studies led to the conclusion that type $13 \beta$-HSD is mainly located in the sebaceous glands [17].

In a further step, androstenedione is activated by conversion to testosterone through androgenic $17 \beta$-hydroxysteroid dehydrogenase (17 $\beta$-HSD). The cutaneous expression of $17 \beta$-HSD was mainly demonstrated in the pilosebaceous unit and epidermal keratinocytes. To date, twelve isoforms of this enzyme have been identified [19,23]. 17 $\beta$-HSD types 3 and 5 form the active androgen testosterone from androstenedione, whereas the oxidative reaction of $17 \beta$-HSD types 2 and 4 is in the reverse direction, inactivating the potent sexual steroids. The human sebaceous gland possesses the cellular machinery needed to transcribe the genes for $17 \beta$-HSD types $1-5$; among them a strong $17 \beta$-HSD2 and $17 \beta$-HSD5 expression have been reported $[17,18,24]$. The predominance of the strongly pro-oxidative $17 \beta$-HSD2 suggests its protective role against the effects of locally excessive amounts of potent androgens [18]. Greater reductive activity of androgenic $17 \beta$-HSD types 3 and 5 was noted in sebaceous glands from the facial than from non-acne prone areas, suggesting an increased net production of potent androgens in facial areas. In addition, $17 \beta$-HSD3 expression was detected in human sebocytes, but not in keratinocytes, further indicating the importance of the sebaceous gland in cutaneous androgen activation [17]. However, scrotal skin $17 \beta$-HSD3 and $17 \beta$-HSD5 expression levels seem to be age-dependent, in that $17 \beta$-HSD 3 mRNA is highly expressed before 2 years of age and again during the teenage years, whereas $17 \beta$-HSD 5 mRNA is predominantly expressed between the age 2 and 13 years and again after 30 years of age [24]. In hair follicles, $17 \beta$-HSD is localized in outer root sheath cells, where it primarily inactivates androgens: early studies showed androstenedione as the major metabolite of cultured human hair follicle keratinocytes incubated with radiolabeled testosterone [19]. Anagen hairs mainly express high levels of type 2 and moderate levels of type $117 \beta$-HSD [25]. 17 $\beta$-HSD enzyme activity has also been shown in cultured epidermal keratinocytes and in the microdissected apocrine sweat glands. $5 \alpha$-Reductase irreversibly converts testosterone to DHT, the most potent naturally occurring androgen in tissue [26]. Two isoforms have been described; type 1 dominates in the skin [27]. 
Expression of this enzyme is predominant in sebaceous and sweat glands, with lesser activity in epidermal cells and hair follicles [9]. Type 2 activity predominates in beard hair follicles. Finally, two isoenzymes of $3 \alpha$-hydroxysteroid dehydrogenase ( $3 \alpha$-HSD) catabolize active androgens to compounds that do not bind the androgen receptor (three isozymes of $3 \alpha$-HSD were initially identified, but the type 2 isozyme has been found to predominantly form testosterone and has been renamed 17 $\beta$-HSD type 5) $[17,28]$. By glucuronidation or sulfation, water soluble steroid metabolites are eliminated through the kidney. Alternatively, aromatase may convert testosterone and androstenedione to estrogens in sebaceous glands, outer as well as inner root sheath cells of anagen terminal hair follicles, and dermal papilla cells [17,29].

More recently, transcription factors regulating steroidogenesis in the classical steroidogenic organs have been demonstrated in the skin. Thus, a review of current literature provides a hint that SOX9 may potentiate steroidogenesis by way of steroidogenic factor1 (SF-1) to activate the steroidogenic acute regulatory protein (StAR), while DAX-1 exhibits an antagonizing function, and WT-1 plays a bimodal tuning role by up-regulating DAX-1 [30].

SF-1 and DAX-1 are detected in skin and its appendages with a distinctive expression pattern. Prominent expression of DAX-1 has been confined to the epidermis, sebaceous glands, sweat glands, and outer root sheath of the hair follicles with weaker expression in the inner root sheath, matrix cells, and dermal papilla cells. Similarly, SF-1 has been detected in the epidermis, but displayed a scattered nuclear pattern across all layers [31,32]. SOX-9 and WT- 1 were also detected in the skin [30]. These data demonstrate that important regulators of steroidogenesis are present in human skin and its appendages. These transcription factors may have a role in cutaneous steroidogenesis and thus be involved in hair follicle pathologies associated with steroids.

\section{Androgens and the sebaceous gland}

Sebaceous gland enlargement and production of sebum are dependent upon androgens, and at puberty, male sebum production modestly increases over that of females [9]. Skin in acne produces higher rates of testosterone and DHT than in healthy individuals. In addition, isolated elevations of plasma DHT and $3 \alpha$-androstenediol glucuronide, postulated by some to be biochemical markers of cutaneous androgen metabolism and action, have been found in female patients with acne [33], but there is considerable evidence that these results primarily reflect adrenal steroid metabolites [9]. Androgens stimulate sebocyte proliferation, an effect dependent on the area of skin from which the sebaceous glands are obtained; facial sebocytes are mostly affected [34]. In contrast, androgens as single compounds seem to be unable to modify sebocyte differentiation, which is stimulated by co-incubation with peroxisome proliferator activated receptor (PPAR) ligands [35,36].

\section{Androgens and the hair follicle}

Androgens have strong effects on hair growth and appear to act through type $25 \alpha$-reductase and the AR on dermal papilla cells $[9,37]$. Single nucleotide polymorphisms of the AR have been associated with hirsutism in women [38] and androgenetic alopecia in men [16]. Dermal papilla cells appear to mediate the growth-stimulating signals of androgens by releasing growth factors that act in a paracrine fashion on the other cells of the follicle [39]. Androgens cause enlargement of hair follicles in androgen-dependent areas (beard in male adolescents, axillary and pubic hair), but in scalp follicles of susceptible men paradoxically androgens foster miniaturization and shortage of hair in the anagen stage leading to common baldness [3]. These contradictory effects may be explained by genetically determined differences in the response of papilla cells to androgens at different body areas [9]. Notably AR mRNA was reported to be expressed in beard and axillary hair dermal papilla cells for both sexes, but only at a low level in those from occipital scalp hair [40]. In addition, very high doses of testosterone and DHT $(10 \mu \mathrm{M})$ were shown to induce apoptosis of dermal papilla cells in association with activation of the bcl-2 pathway [41]. The skin of hirsute women forms excessive DHT, but it is unclear whether this is formed by the hair follicles themselves or by the associated sebaceous gland hyperplasia [42]. Men with a deficiency of type $25 \alpha$-reductase provided the initial clue that conversion of testosterone to the more potent DHT by this enzyme enhances androgenic effects on hair follicles. These individuals produce little or no beard growth and do not develop androgenetic alopecia [43]. Subsequently the inhibition of type $25 \alpha$-reductase by finasteride has been proven to slow or even reverse the progression of androgenetic alopecia [44]. Currently, higher levels of StAR and type $13 \beta$-HSD were detected in the scalp of men with androgenetic alopecia [45].

\section{Further effects of androgens on human skin}

Androgens appear to promote perspiration since males sweat at a greater rate than females in similar situations [46]. This difference between the sexes arises during puberty. Sweat glands contain over half of skin $5 \alpha$-reducatase activity and express the enzymes necessary to form DHT from DHEA, as well as AR. However, the sweat gland secretion rate is not directly influenced by androgens: androgen treatment has not stimulated sweat production in adult women, and anti-androgen application to the skin of males has not decreased the sweat rate. Therefore, androgens have been postulated to initiate the factors required for the different sweat secretion rate between the sexes during puberty, but do not maintain the function of the glands. It is likely that the androgen effect is exerted on the differentiation of the apoeccrine sweat glands. This type of sweat glands, a hybrid of this eccrine and apocrine glands, develops during puberty from eccrine or eccrine-like precursor glands, but the secretory rate is seven-fold higher in response to similar innervation. Given that these glands comprise up to $45 \%$ of the axillary glands in patients with hyperhidrosis, they probably play a major role in the pathophysiology of this condition. Hyperhidrosis has been reported to be the sole skin manifestation of androgen excess. A few studies have indicated that the apocrine gland of patients with excessive or abnormal odor (osmidrosis), irrespective of sex, is a typical androgen target organ [47]. Type $15 \alpha$-reductase predominates in the apocrine sweat glands of such patients [48].

Adult male skin is thicker and drier than female skin. This is in part because androgen stimulates epidermal hyperplasia and suppresses epidermal barrier function in fetal and adult human skin [49]. Testosterone replacement treatment has been reported to have a similar effect on barrier function in castrated adult mice and an adult man with hypopituitarism. Ashcroft and Mills [50] observed in a hairless mouse model that endogenous testosterone inhibition of cutaneous wound healing was AR-mediated. However, further work, especially in humans, is required to better understand the enhanced inflammatory response suggested by these and other authors [51,52]. 


\section{Androgens, seborrhea and acne}

The obligatory role of androgens in the pathophysiology of acne has long been recognized and corroborated by clinical and experimental observations and therapeutic experience. Clinical observations supporting the pathogenic role of androgens in acne, include close association between the normal onset of microcomedonal acne in prepubertal children with the adrenarcheal rise in circulating DHEA-S levels [53], acne formation in small children with virilizing tumors or congenital adrenal hyperplasia (CAH) [54], hyperandrogenism identified in women with sudden exacerbation of acne, persistent acne beyond 30 years of age and therapy-refractory acne, absence or rarity of acne in men with androgen insensitivity syndrome or early castration before puberty [55], induction of acne by systemic or topical administration of androgens or anabolic steroids [56], and positive associations between serum androgen levels and acne lesion counts in men and women [57]. In vitro studies using sebaceous gland organ culture, rat prepucial glands, and primary culture or immortalized human sebocytes have all demonstrated the expression of the enzymes necessary for the synthesis and metabolism of androgens $[17,27,58,59]$. However, the in vitro effect of supplemented androgens on the cell division and lipogenesis varies, depending partly on the culture conditions $[34,35,58,60,61]$. Hormonal treatment of acne in female patients using various methods of suppressing androgen secretion or action suppresses sebum production by $12.5-65 \%$ and is beneficial as monotherapy for female patients with mild to moderate acne $[62,63]$.

In addition to stimulation of sebum production, indirect evidence also suggests the importance of androgens on comedogenesis and inflammation: higher activity of type $15 \alpha$-reductase in the follicular infrainfundibulum, indicating increased capacity for producing androgens [64] and significant association between inflammatory lesions in adult women with acne and serum androgens $[9,65]$. On the other hand, in vitro findings indicated that stress factors, such as the corticotrophin-releasing hormone, increases $3 \beta$-HSD mRNA levels, implying that stress and inflammation may also augment androgenesis in sebocytes [66].

Functional studies are needed to prove the significance of the expression of the steroidogenic enzymes identified and localized in human skin, especially in sebaceous glands. Moreover, quantitative differences of the enzyme activities between normal healthy and acne-prone skin should be precisely determined before the design of potential drugs and the advancement of their clinical use.

\section{Expression of steroidogenic enzymes in acne patients}

The distribution and strong activities of various hydroxysteroid dehydrogenases in human sebaceous glands in acne-prone as compared to non-acne skin have long been observed [67]. While there was no difference in the rates of enzymatic hydrolysis of steroid sulfatase between the freshly obtained epidermal tissue of acne-prone and normal skin [20], a novel non-estrogenic inhibitor of steroid sulfatase, 6-[2-(adamantylidene)hydroxyben zoxazole]-O-sulfamate, was shown to effectively block the enzyme in the skin leading to a reduction of sebum secretion in animal studies [68]. However, although an exclusive predominance of type $15 \alpha$-reductase has been demonstrated in sebaceous glands, with higher enzyme activity in facial skin than in nonacne-prone skin $[27,69]$, there seems to be no relationship between the activity of $5 \alpha$-reductase or $17 \beta$-HSD in sebaceous glands and the presence or absence of acne in both sexes [70]. Moreover, in a 3-month, multicenter, randomized, placebo-controlled clinical trial, the use of a potent selective inhibitor of type $15 \alpha$-reductase alone or in combination with systemic minocycline was not associated with clinical improvement of acne [71]. On the other hand, enhanced expression of type $25 \alpha$-reductase was revealed in the hair follicle but not in the sebaceous glands in inflammatory acne lesions [72]. Greater activity of type $217 \beta$ HSD, the isozyme working in the opposite oxidizing direction to inactivate androgens [73], was found in sebaceous glands from nonacne-prone areas as compared to sebaceous glands obtained from facial skin [18].

\section{Androgen excess}

Cutaneous manifestations - seborrhea, acne, hirsutism, malepattern alopecia, i.e., SAHA syndrome when full-blown [74] are prominent symptoms of peripheral androgen excess. Androgen excess occurs by increased circulating androgens (hyperandrogenemia) or by increased intracellular levels of androgens in the skin (hyperandrogenism). Hyperandrogenemia arises from ovarian or adrenal dysfunction or tumors, disturbed peripheral metabolism of androgen precursors, or exogenous androgenic medications [3]. Polycystic ovary syndrome, a polymorphic disorder, accounts for over 90 percent of cases. This hyperandrogenic disorder is often associated with insulin resistance and acanthosis nigricans in obese women, a combination termed HAIR-AN syndrome [75]. Other important causes, in order of decreasing frequency, are $\mathrm{CAH}$, hyperprolactinemia, Cushing's syndrome, gonadal or adrenal neoplasms, disorders of sexual differentiation, and corpus luteum dysfunctions of pregnancy. Exogenous (iatrogenic) causes of androgen excess include testosterone, anabolic steroids, the androgenic progestin danazol, and valproic acid [3].

In CAH, defects of enzymes involved in adrenal cortisol synthesis result in inefficient cortisol biosynthesis [76]. This is compensated by an increased pituitary secretion of adrenocorticotropic hormone. Thus, normal cortisol blood levels may be achieved, but at the cost of an excess production of adrenal androgens, which is responsible for clinical signs. The enzyme most often defective in adrenal hyperplasia (over 95\%) is 21hydroxylase. In a few instances, other intermediary enzymes are responsible (11 $\beta$-hydroxylase, $3 \beta$-HSD or P450 oxidoreductase) $[76,77]$. 21-Hydroxylase deficiency is an autosomal recessive disorder. Various mutations affecting both alleles of the gene lead to variable degrees of impairment of 21-hydroxylase activity [76]. Severe defects produce classic forms, which manifest themselves in infancy (virilization, genital ambiguity in girls, and, if mineralocorticosteroids are also deficient, salt wasting) or in childhood (pseudoprecocious puberty). Mild defects, one of the most common genetic disorders in man, cause nonclassic, late onset presentations, in which less severe signs occur later in childhood or during or after puberty including premature pubarche, acne, hirsutism, or irregular menses; this form may even remain asymptomatic (cryptic form).

There may be a tendency to underestimate the role of androgen excess in men with acne. Indeed, a few published studies indicate the relevance of this phenomenon. Men with persistent acne had significantly higher serum levels of androgens than age-matched controls [78], and excess androgens of adrenal origin were frequently detected in men with severe (cystic) acne [6]. 


\section{Hypogonadism}

Skin signs of hypogonadism are thin, weak hair with a reduced number of terminal hair follicles on the face and the axilla and a feminine pattern of pubic hair, as well as lack of seborrhoea, acne and androgenetic alopecia, along with penis and testicular atrophy [79].

\section{Treatment of androgen excess-associated disorders}

The major thrust of drug design for treatment of androgen-associated disorders, so far, has been directed against several levels of androgen function and metabolism [19]. However, only partial effectiveness has been achieved either by androgen depletion, inhibition of androgen metabolism or blockade of the AR. In addition, major adverse events can occur, since effectiveness is only associated with systemic application of such compounds.

Acne, hirsutism, and androgenetic alopecia of female pattern as manifestations of systemic or local androgen excess are best treated by eliminating the cause (e.g., tumors, drugs) or by interfering with androgen secretion or action. Oral contraceptives are used in women with polycystic ovary syndrome or idiopathic hirsutism [41]; both estrogens and progestins contribute to the androgen-suppressive effect $[62,80]$. Anti-androgens such as high-dose cyproterone acetate or spironolactone exhibit the strongest anti-androgenic activity among progestins [41]; they must be used with contraception because anti-androgens interfere with the differentiation of the genitalia of the fetal male. The combination of drospirenone with a low dose estrogen seems to be as effective as the combination low-dose cyproterone acetate and estrogen $[80,81]$. In male acne patients with $\mathrm{CAH}$, low-dose glucocorticoids (e.g., methylprednisolone $4 \mathrm{mg}$ every other day at bedtime) have been used to suppress ACTHmediated adrenal androgen production [82]. These hormonal treatments are best combined with other anti-acne regimens for a quicker relief [83]. Finasteride is the first selective androgenmetabolizing enzyme inhibitor introduced, targeting androgenetic alopecia in men [19].

\section{Estrogens and skin \\ $\checkmark$}

\section{Estrogens and human skin}

A number of studies have shown that estrogens have many important beneficial and protective roles in skin physiology $[84,85]$. Estrogens can delay or prevent skin aging manifestations by reducing epidermal thinning and maintaining skin thickness and hydration [86-88]. In postmenopausal women skin collagen content decreases at the rate of $2 \%$ per year [89], while estradiol treatment can significantly increase hydroxyproline content [90]. Skin elasticity also correlates negatively with years since menopause, while hormone replacement therapy increases elasticity by $5 \%$ over a year [91]. Estrogens also accelerate cutaneous wound healing [92], and many women notice an improvement in inflammatory skin disorders, such as psoriasis during pregnancy [93-95]. Epidemiological studies indicate that the mortality rates from non-melanoma skin cancer [96] and melanoma [97] are significantly lower in women.

Binding studies on whole human skin homogenates have demonstrated the existence of estrogen-binding sites, although receptor levels vary with body site, with higher numbers in facial skin compared to thigh or breast $[98,99]$. Recent studies have begun to localize the molecular and cellular basis of these findings.

\section{The estrogen receptors}

Two distinct intracellular estrogen receptors (ER), ER $\alpha$ and ER $\beta$, have been identified that belong to the superfamily of nuclear hormone receptors [100]. ER $\alpha$ and ER $\beta$ share approximately $60 \%$ homology in the ligand binding domain, but bind estradiol with a similar affinity [101]. More recently it has been demonstrated that estrogens can also act independently of their classical genomic pathway [102]. Rapid cellular responses to estrogens, much faster than that can be attributed to genomic signaling, provide evidence that cell membrane estrogen receptors exist. These receptors can activate signaling cascades via conventional second messengers, including adenylate cyclase, cAMP, phospholipase $C$, protein kinase $C$, mitogen-activated protein kinase and ligand or voltage-gated ion channels [103-108]. In some cells $\operatorname{ER} \beta$ counteracts $\mathrm{ER} \alpha$, in some cases acting as an ER $\alpha$ heterodimer to inhibit the transactivating function of $\mathrm{ER} \alpha$, and in other cases acting as a homodimer to regulate specific genes, many of which are anti-proliferative [109].

\section{Estrogens and epidermal keratinocytes}

Recently, it has been demonstrated by immunohistochemistry that $\operatorname{ER} \beta$ is the predominant estrogen receptor in adult human scalp skin, where it is strongly expressed in the stratum basale and stratum spinosum of the epidermis [110-112]. A recent study using semi-quantitative RT-PCR has confirmed ER $\beta$ mRNA expression in the skin of the midgestational human fetus [113]. Further work has demonstrated that human epidermal keratinocytes express only ER $\beta$ mRNA and protein by RT-PCR [114] and western blotting [115]. In contrast, an investigation of the high affinity estrogen-binding sites in human neonatal foreskin epidermal keratinocytes showed expression of both $\mathrm{ER} \alpha$ and $\mathrm{ER} \beta$ by immunocytochemistry and northern blotting [116]. The difference between these studies of ER expression may be due to culture conditions: since keratinocytes expressing both receptors were cultured in media containing phenolred, which has estrogenic activity [117], and estradiol can up-regulate ER $\alpha$ expression in cultured keratinocytes [116], skin ER $\alpha$ may be up-regulated by estrogenic compounds. Recent studies have also demonstrated that estradiol conjugated with bovine serum albumin can stimulate both epidermal keratinocyte proliferation and DNA synthesis [118], and estradiol increases phosphorylation levels of ERK1 and ERK2 kinases within 15 minutes in such cells [116]; both are indications that estradiol can activate nongenomic signaling pathways in the epidermis.

\section{Estrogens and dermal fibroblasts}

Primary cultures of human dermal fibroblasts from female skin have been shown to express both mRNA and protein for ER $\alpha$ and ER $\beta$ [119]. Although they co-express both receptors, immunocytochemistry showed some variation in their expression. $\mathrm{ER} \beta$ was predominately nuclear, while $\mathrm{ER} \alpha$ was expressed in both the cytoplasm and the nucleus. Furthermore, mRNA levels for ER $\beta$ were higher than levels of ER $\alpha$. The same group also demonstrated that estradiol up-regulates $\operatorname{ER} \beta$ expression in dermal fibroblasts cultured from postmenopausal women [120].

\section{Estrogens and the pilosebaceous unit \\ The hair follicle}

Estrogens appear to stimulate hair growth in man [9]. They are thought to prolong the anagen phase of scalp hair growth by increasing cell proliferation rates and postponing their transition to the telogen phase. In an organ culture system, estradiol 
stimulates hair shaft elongation in fronto-temporal male hair follicles [121]. Estrogens in low dosage modestly stimulate pubic and axillary hair growth of hypogonadal girls, independently of changes in androgen levels. It is possible that this effect of estrogens on hair growth is mediated in part by induction of androgen receptors, as is the case in brain, or by increase in insulin-like growth factor-I levels. In late pregnancy, when estrogen levels are high, a high proportion of scalp hair follicles remain in anagen. Postpartum, a large number of hair follicles simultaneously advance into telogen phase, causing loss of a large number of hairs. This postpartum telogen effluvium has been postulated to be caused by the rapid decrease of estrogens at the time of delivery causing a large number of hair follicles to simultaneously advance into telogen. On the other hand, estrogens significantly inhibit hair growth in a number of other mammalian species $[84,85]$. The estradiol-induced delay in the transition from the telogen to anagen phase in the mouse hair growth cycle appears to be mediated by the ER $\alpha$ of dermal papilla cells [122]. ER-null and aromatase-null mice are virilized and so have not proven to be a useful model for understanding the role of estrogens in hair and skin. In situ, immunohistochemical studies have shown that $\mathrm{ER} \beta$ is strongly expressed in human scalp anagen hair follicles in contrast to ER $\alpha[29,112]$. While there are no reports of ER expression in human telogen follicles, in the murine hair cycle ER $\alpha$ expression is maximal in the telogen follicle [123]. Human hair follicles in culture express ER $\beta$, although the distribution pattern by immunohistochemistry appears to be gender-specific [124]: $\operatorname{ER} \beta$ immunoreactivity predominated in the female follicular dermal papilla, which appears to determine the type of hair produced [125], and although basal levels were much lower in male follicles, they could be up-regulated by estradiol. Dermal papilla cells cultured from female follicles expressed mRNA for both ER $\alpha$ and $\mathrm{ER} \beta$. Immunocytochemistry has demonstrated co-expression of $\operatorname{ER} \alpha$ and $\operatorname{ER} \beta$ although there was some variation; $\operatorname{ER} \beta$ was predominately nuclear, while ER $\alpha$ was expressed in the cytoplasm and the nucleus [29]. This is similar to the observation of ER expression in dermal fibroblasts [119]; however, in contrast to mRNA levels in dermal fibroblasts [120], in cultured follicular dermal papilla cells mRNA levels for ER $\alpha$ were approximately 2-fold higher than $\operatorname{ER} \beta$ [29]. In addition, the expression of ER $\alpha$ mRNA in cultured follicular dermal papilla cells was down-regulated by dexamethasone, while ER $\beta$ expression remained unaffected [29].

\section{The sebaceous gland}

Estrogens suppress sebaceous gland size and function, both indirectly and directly, by pituitary-gonadal suppression of androgen production [9]. The estrogen effect is clear at the $35 \mu \mathrm{g}$ dose of ethynylestradiol in oral contraceptive pills. The dose of estrogen required to suppress sebum production appears to be greater than the dose required to suppress ovulation [32]. In vitro studies with the addition of estradiol failed to show a regulatory effect on cell proliferation $[35,58]$, while the inhibition of lipogenesis varied in different animal studies $[35,125,126]$. When administered systemically, estrogens produce a reduction in size and secretion of sebaceous glands in both human sexes [127].

Immunostaining of human skin has shown that $\operatorname{ER} \alpha$ and $\operatorname{ER} \beta$ are co-localized in different sebocytes [110-112], while basal sebocytes only display ER $\alpha$ [128]; the significance of this finding remains to be determined. The human epidermis, unlike most steroidogenic organs abundant in $\mathrm{ER} \alpha$, mainly expresses $\mathrm{ER} \beta$.

\section{The apocrine gland}

Similar to the sebaceous gland, the apocrine gland develops from the hair follicle and remains attached to it, increasing in size and activity with sexual maturity. A recent study has confirmed by both immunohistochemistry and RT-PCR that ER $\beta$ is expressed in the human axillary apocrine gland [129]. Although the apocrine secretory epithelium exhibited strong nuclear and cytoplasmic staining for $\operatorname{ER} \beta$, there was no expression of $\mathrm{ER} \alpha$, as also confirmed by RT-PCR [129].

\section{The eccrine glands}

Although the role of estrogens in the eccrine glands is unclear, recent immunohistochemical studies by two separate laboratories have demonstrated the presence of $\operatorname{ER} \beta$, but not $\mathrm{ER} \alpha$ in human eccrine glands $[110,112]$.

\section{Estrogens and aromatase}

Aromatase, the product of the CYP19 gene, catalyzes three consecutive hydroxylation reactions converting C19 androgens to C18 estrogens [130]. Aromatase is also present in various extragonadal tissues and its expression is regulated in part by means of tissue-specific promoters through the alternative splicing mechanism on multiple exon 1 variants[131]. At least six variants of exon 1 have been described; exons $1 \mathrm{a}, 1 \mathrm{~b}, 1 \mathrm{c}, 1 \mathrm{~d}, 1 \mathrm{e}$ and $1 \mathrm{f} \mathrm{that} \mathrm{are} \mathrm{specific} \mathrm{for} \mathrm{expression} \mathrm{in} \mathrm{the} \mathrm{placenta,} \mathrm{skin} \mathrm{fibroblasts/}$ fetal liver/adipose tissue/vascular tissue, ovary, ovary/prostate, placenta, and fetal brain, respectively $[132,133]$.

By immunohistochemical examination, aromatase was found in the outer root sheath of anagen, terminal hair follicles and in sebaceous glands, but rarely in telogen hair follicles [134]. The higher expression of aromatase in the scalp hair follicles of women than men, particularly on the occiput, has suggested that local estrogen formation from testosterone may play a role in protecting them from alopecia [134]. Aromatase activity has been reported in the pilosebaceous unit [135], keratinocytes cultured in serum-free medium [136], fibroblasts from both genital and non-genital skin [137] and fibroblasts from adipose tissue [138]. However, in a recent study by Chen et al. (unpublished data), the mRNA expression of aromatase was under the detection limit in the total scalp extract from either bald or occipital area of men with androgenetic alopecia.

\section{Estrogens and acne}

Although the efficacy of ethynylestradiol-containing oral contraceptives has been confirmed and approved in acne treatment, very little is known about the role of estrogens in pathogenesis of acne formation. The quantitative difference of ER $\alpha$ and $\operatorname{ER} \beta$ between normal and acne skin remains to be determined, although significant differences in the number of estrogen receptors between normal and acne-bearing skin was found to exist in both sexes [127].

\section{Estrogens and melanocytes \\ Normal melanocytes}

Hyperpigmentation of the face is commonly seen in pregnant women and may be accompanied by increased pigmentation in areas such as the areolae, linea alba and perineal skin, all of which usually fade following parturition [139]. Estrogen containing oral contraceptives can also cause facial hyperpigmentation [140] and estrogen-containing ointments can cause intense pigmentation of the genitals, mammary areola and linea alba in male and female infants [141]. Recently, using a double immun- 
ofluorescence method, human scalp epidermal melanocytes have been shown to express both $\operatorname{ER} \alpha$ and $\operatorname{ER} \beta$ in situ [142], and others have confirmed by ligand binding studies that cultured human epidermal melanocytes contain ER [143]. A more recent immunocytochemical study has reported that human melanocytes cultured from adult foreskin express ER, although it is unknown whether this is $\operatorname{ER} \alpha$ or $\operatorname{ER} \beta$ [144]. Human female scalp melanocytes express $\operatorname{ER} \alpha$ and $\operatorname{ER} \beta$ in culture [145], and the induction of pigmentation in these cells up-regulates $\mathrm{ER} \alpha$ but not $\operatorname{ER} \beta[146]$.

\section{Melanoma}

The effects of estrogens on melanoma are poorly understood, apparently because estrogen receptors are variably expressed in melanoma cell lines [147-149]. Thornton et al. have recently shown that pigment induction leads to an increase in the expression of both ER $\alpha$ and ER $\beta$ in a poorly pigmented melanoma cell line $[145,146]$ suggesting that pigment cell phenotype may be regulated via ER.

\section{Future therapeutic concepts of estrogen-related disorders}

Since estrogens, presumably acting via ER, have important effects on skin ageing, pigmentation, hair growth, sebum production, wound healing and skin cancer, there is a pressing need to understand the complex interactions between estrogens, their receptors and other signaling events. The recent advances in the development of selective ligands, selective ER modulators and activators of nongenotrophic estrogen-like signaling, may help to answer the outstanding questions regarding estrogenassociated disorders in human skin.

\section{Progestins and skin \\ $\nabla$}

\section{Human skin and progestins}

All progestins have the unique effect of increasing body core temperature. Natural progesterone has no known influence on human skin other than exerting this effect at normal luteal phase levels. This progestin action results from raising the thermoregulatory set-point at which sweating occurs [150]; evidence for a direct effect on cutaneous vasomotor tone is inconclusive [151]. However, synthetic progestins have varying degrees of clinically significant androgenic, anti-androgenic, anti-mineralocorticoid and glucocorticoid side-effects (Table 1). Nevertheless, androgenic progestins such as norethindrone and levonorgestrel have been important in cutaneous medicine in combination with estrogen in the treatment of hirsutism and acne. Consequently, pharmaceutical development efforts have centered on developing new generations of synthetic progestins such as drospirenone with selectively improved anti-androgenic and anti-mineralocorticoid profiles.

\section{Mode of action and effects of progestins}

All progestins have corticoid, anti-corticoid, androgenic, and anti-androgenic effects. Discovery of these properties dates to discovery of the anti-mineralocorticoid effect of progesterone itself [152], which led to the development of the progesterone analogue spironolactone as an anti-mineralocorticoid [153] with little progestational activity [154]. Subsequently, the progesterone analogue cyproterone acetate was found to be a potent antiandrogen $[80,82,155]$. The anti-androgenicity of spironolactone was later recognized [156] and served as the basis for the recent development of the unique progestin drospirenone [80,81]. Meanwhile, the search for orally active progestins led to the discovery of the progestational effects of the 19-nortestosterone analogues that are the gestogenic components of most oral contraceptives [157]. They are structurally androgenic and generate estrogenic or anti-estrogenic metabolites to varying degrees.

The molecular basis of the relatively promiscuous pattern of signaling by progestins is due to high homology among the DNA binding domains (75\%) and modest homology among the ligand binding domains ( $\geq 50 \%$ ) of progestin, mineralocorticoid, glucocorticoid and androgen receptors $[158,159]$. A new weakly gestogenic 19-nortestosterone derivative, tibolone, which has estrogenic effects on climacteric symptoms and bone and significant androgenic effects, is now marketed in Europe [160,161]. A new generation of "pure" progestins based on 19-norprogesterone is under development. The clinically important endocrine properties of commonly used gestogens are summarized in Table 1 [80,81, 152-154, 156, 162-166].

The effects of progestins are not necessarily direct or genomic. Combination with estrogen in oral contraceptives enhances gonadotropin suppression of ovarian androgen production. Progesterone itself also complements estrogen effects on fluid retention by lowering the osmotic threshold for vasopressin release [150]. Unique structural features of individual agents are responsible for other actions, such as inhibition of $5 \alpha$-reductase and

Table 1 Endocrine profiles of commonly used progestins. Potency estimates are semiquantitative composites of clinical and animal studies

\begin{tabular}{|c|c|c|c|c|}
\hline Type of progestin & Anti-androgenic activity & Androgenic activity & $\begin{array}{l}\text { Anti-mineralocorticoid } \\
\text { activity }\end{array}$ & Glucocorticoid activity \\
\hline \multicolumn{5}{|l|}{ Progesterone-derived } \\
\hline Chlormadinone acetate & \pm & 0 & \pm & + \\
\hline Cyproterone acetate & ++ & 0 & 0 & + \\
\hline Drospirenone & + & 0 & + & 0 \\
\hline $\begin{array}{l}\text { Medroxyprogesterone } \\
\text { acetate }\end{array}$ & \pm & \pm & 0 & + \\
\hline Progesterone & \pm & 0 & + & \pm \\
\hline \multicolumn{5}{|c|}{ Nortestosterone-derived } \\
\hline Desogestrel & 0 & \pm & 0 & 0 \\
\hline Levonorgestrel & 0 & ++ & 0 & 0 \\
\hline Norethindrone & 0 & + & 0 & 0 \\
\hline Norgestimate & 0 & \pm & 0 & 0 \\
\hline
\end{tabular}

++ Indicates the most potent side-effect of its class, + indicates a small but clinically significant effect of doses used therapeutically, and \pm indicates an equivocal effect 
inactivation of cytochrome P-450 by spironolactone $[151,167]$ or $3 \beta$-HSD inhibition by cyproterone acetate $[17,80,155]$. Medroxyprogesterone acetate, but not progesterone itself, inhibits estrogen-induced vasodilation, which involves both genomic and non-genomic activation of nitric oxide synthase, while norethisterone has a non-genomic vasodilator effect $[165,168,169]$.

Although $3 \beta$-HSD, the enzyme capable of converting pregnelolone to progesterone, has been characterized and localized in human skin, the production of progesterone has not yet been directly demonstrated in sebaceous glands [170]. Progesterone receptors are detected in nuclei of human sebaceous gland cells, and the effect of progesterone on sebum production in animal models varies in different studies, depending on the species and sex of the animals [127,171-174].

\section{Progestins and skin disorders}

The major use of progestins in skin disorders is in the treatment of hirsutism and acne vulgaris, where they are prescribed as components of estrogen-progestin combination pills and as anti-androgens [175]. Estrogen-progestin treatment can reduce the need for shaving by half and arrest progression of hirsutism of various etiologies, but does not necessarily reverse it. In contrast, they are effective in reducing acne. It is unclear whether those combinations with non-androgenic progestins are more effective in reducing lesions. However, they are to be favored because they do not inhibit the beneficial effect of estrogen on the serum lipid profile; those with drospirenone have the additional advantage of counteracting estrogen-induced sodium retention $[63,176,177]$. Cyproterone acetate and spironolactone are similarly effective as anti-androgens in reducing hirsutism, although there is wide variability in individual responses.

Whether progestins play a direct role in hair cycling is unknown. Although telogen effluvium has been attributed to high estrogen or prolactin levels, the settings in which these hormones are incriminated (pregnancy and oral contraceptive use) $[178,179]$ are related to high progestin states as well.

Progestins are effective in reducing post-menopausal hot flashes [161]. This is likely to mainly result from action on the central nervous system [180].

\section{Acknowledgements}

$\nabla$

The studies of CCZ are supported by BMBF and NGFN-2 grants. MJT is indebted to Drs I. Laing, L. Nelson, A. Messenger, A. Taylor, D. Tobin, and Ms A. Meskiri and S. Stevenson for their help and encouragement relating to various aspects of her work and contribution to this article. The studies of RR are supported in part by USPHS grant U54-041859 and RR-00055, and KQ studies are supported in part by K08-HD043279.

\section{Affiliations}

Departments of Dermatology and Immunology, Dessau Medical Center, Dessau, Germany

2 Laboratory of Biogerontology, Dermato-Pharmacology and Dermato-Endocrinology, Institute of Clinical Pharmacology and Toxicology, Charité Universitaetsmedizin Berlin, Campus Benjamin Franklin, Berlin, Germany Department of Dermatology, Chang Gung Memorial Hospital-Kaohsiung Medical Center, Chang Gung University College of Medicine, Kaohsiung, Taiwan

Division of Medical Biosciences, University of Bradford, Bradford, UK

5 Department of Pediatrics, The University of Chicago Pritzker School of Medicine, Comer Children's Hospital, Chicago, IL, USA
6 Department of Medicine, Section of Pediatric Endocrinology, The University of Chicago Pritzker School of Medicine, Comer Children's Hospital, Chicago, IL, USA

\section{References}

1 Imperato-McGinley J, Gautier T, Cai L-Q Yee B, Epstein J, Pochi P: The androgen control of sebum production. Studies of subjects with dihydrotestosterone deficiency and complete androgen insensitivity. J Clin Endocrinol Metab 1993; 76: 524-528

2 Zouboulis CC: Human skin: an independent peripheral endocrine organ. Horm Res 2000; 54: 230-242

3 Rosenfield RL: Hirsutism and the variable response of the pilosebaceous unit to androgen. J Investig Dermatol Symp Proc 2005; 10: 205-208

4 Rosenfield RL: Role of androgens in growth and development of the fetus, child, and adolescent. Adv Pediatr 1972; 19: 171-213

5 Stewart ME, Downing DT, Cook JS, Hansen JR, Strauss JS: Sebaceous gland activity and serum dehydroepiandrosteron sulfate levels in boys and girls. Arch Dermatol 1992; 128: 1345-1348

6 Marynick SP, Chakmakjian ZH, McCaffree DL, Herndon JH: Androgen excess in cystic acne. N Engl J Med 1983; 308: 981-986

7 Pochi PE, Strauss JS: Sebaceous gland response in man to the administration of testosterone, $\Delta 4$-androstenedione, and dehydroisoandrosterone. J Invest Dermatol 1969; 52: 32-36

8 Messenger AG: The control of hair growth: an overview. J Invest Dermatol 1993; 101: 4S-9S

9 Deplewski D, Rosenfield RL: Role of hormones in pilosebaceous unit development. Endocrine Rev 2000; 21: 363-392

10 Verrijdt $G$, Haelens A, Claessens F: Selective DNA recognition by the androgen receptor as a mechanism for hormone-specific regulation of gene expression. Mol Genet Metab 2003; 78: 175-185

11 Zouboulis CC: The human skin as a hormone target and an endocrine gland. Hormones 2004; 3: 9-26

12 Zouboulis CC, Degitz K: Androgen action on human skin - From basic research to clinical significance. Exp Dermatol 2004; 13 (Suppl 4): 5-10

13 Gad YZ, Berkovitz GD, Migeon CJ, Brown TR: Studies of up-regulation of androgen receptors in genital skin fibroblasts. Mol Cell Endocrinol 1988; 57: 205-213

14 Fimmel S, Saborowski A, Térouanne B, Sultan C, Zouboulis CC: Inhibition of the androgen receptor by antisense oligonucleotides regulates the biological activity of androgens in SZ95 sebocytes. Horm Metab Res, in press

15 Ibanez L, Ong KK, Mongan N, Jaaskelainen J, Marcos MV, Hughes IA, De Zegher F, Dunger DB: Androgen receptor gene CAG repeat polymorphism in the development of ovarian hyperandrogenism. J Clin Endocrinol Metab 2003; 88: 3333-3338

16 Hillmer AM, Hanneken S, Ritzmann S, Becker T, Freudenberg J, Brockschmidt FF, Flaquer A, Freudenberg-Hua Y, Jamra RA, Metzen C, Heyn $U$, Schweiger N, Betz RC, Blaumeiser B, Hampe J, Schreiber S, Schulze TG, Hennies HC, Schumacher J, Propping P, Ruzicka T, Cichon S, Wienker TF, Kruse R, Nothen MM: Genetic variation in the human androgen receptor gene is the major determinant of common early-onset androgenetic alopecia. Am J Hum Genet 2005; 77: 140-148

17 Fritsch M, Orfanos CE, Zouboulis CC: Sebocytes are the key regulators of androgen homeostasis in human skin. J Invest Dermatol 2001; 116: 793-800

18 Thiboutot D, Martin P, Volikos L, Gilliland K: Oxidative activity of the type 2 isozyme of 17 beta-hydroxysteroid dehydrogenase (17 betaHSD) predominates in human sebaceous glands. J Invest Dermatol 1998; 111: 390-395

19 Chen $W$, Thiboutot D, Zouboulis CC: Cutaneous androgen metabolism - Basic research and clinical perspectives. J Invest Dermatol 2002; 119: 992-1007

20 Milewich L, Sontheimer RD, Herndon JH, Jr: Steroid sulfatase activity in epidermis of acne-prone and non-acne-prone skin of patients with acne vulgaris. Arch Dermatol 1990; 126: 1312-1314

21 Billich A, Rot A, Lam C, Schmidt JB, Schuster I: Immunohistochemical localization of steroid sulfatase in acne lesions: implications for the contribution of dehydroepiandrosterone sulfate to the pathogenesis of acne (abstract). Hormone Res 2000; 53: 99

22 Hoffmann R, Rot A, Niiyama S, Billich A: Steroid sulfatase in the human hair follicle concentrations in the dermal papilla. J Invest Dermatol 2001; 117: 1342-1348

23 Sakurai N, Miki Y, Suzuki T, Watanabe K, Narita T, Ando K, Yung TM, Aoki D, Sasano H, Handa $H$ : Systemic distribution and tissue localizations of human 17beta-hydroxysteroid dehydrogenase type 12 . J Steroid Biochem Mol Biol 2006; 99: 174-181 
24 Hoppe U, Holterhus PM, Wunsch L, Jocham D, Drechsler T, Thiele S, Marschke C, Hiort O: Tissue-specific transcription profiles of sex steroid biosynthesis enzymes and the androgen receptor. J Mol Med 2006; 84: 651-659

25 Courchay G, Boyera N, Bernard BA, Mahe Y: Messenger RNA expression of steroidogenesis enzyme subtypes in the human pilosebaceous unit. Skin Pharmacol 1996; 9: 169-176

26 Grino PB, Griffin JE, Wilson JD: Testosterone at high concentrations interacts with the human androgen receptor similarly to dihydrotestosterone. Endocrinology 1990; 126: 1165-1172

27 Chen W, Zouboulis CC, Fritsch M, Blume-Peytavi U, Kodelja V, Goerdt $S$, Luu-The V, Orfanos CE: Evidence of heterogeneity and quantitative differences of the type $15 \alpha$-reductase expression in cultured human skin cells - First evidence of its presence in melanocytes. J Invest Dermatol 1998; 110: 84-89

28 Qin K, New MI, Cheng KC: Molecular cloning of multiple cDNAs encoding human enzymes structurally related to 3 alpha-hydroxysteroid dehydrogenase. J Steroid Biochem Mol Biol 1993; 46: 673-679

29 Thornton MJ, Nelson LD, Taylor AH, Birch MP, Laing I, Messenger AG: The modulation of aromatase and estrogen receptor alpha in cultured human dermal papilla cells by dexamethasone: a novel mechanism for selective action of estrogen via estrogen receptor beta? J Invest Dermatol 2006; 126: 2010-2018

30 Chen W, Yang CC, Liao CY, Hung CL, Tsai SJ, Chen KF, Sheu HM, Zouboulis CC: Expression of sex-determining genes in human sebaceous glands and their possible roles in pathogenesis of acne. J Eur Acad Dermatol Venereol 2006; 20: 846-852

31 Patel MV, McKay IA, Burrin JM: Transcriptional regulators of steroidogenesis, DAX-1 and SF-1, are expressed in human skin. J Invest Dermatol 2001; 117: 1559-1565

32 Thiboutot $D$, Chen $W$ : Update and future of hormonal therapy in acne. Dermatology 2003; 206: 57-67

33 Lookingbill DP, Horton R, Demers LM, Egan N, Marks JG, Jr, Santen RJ: Tissue production of androgens in women with acne. J Am Acad Dermatol 1985; 12: 481-487

34 Akamatsu H, Zouboulis CC, Orfanos CE: Control of human sebocyte proliferation in vitro by testosterone and 5-alpha-dihydrotestosterone is dependent on the localization of the sebaceous glands. J Invest Dermatol 1992; 99: 509-511

35 Chen W, Yang C-C, Sheu H-M, Seltmann H, Zouboulis CC: Expression of peroxisome proliferator-activated receptor and CCAAT/enhancer binding protein transcription factors in cultured human sebocytes. J Invest Dermatol 2003; 121: 441-447

36 Makrantonaki E, Zouboulis CC: Testosterone metabolism to $5 \alpha$-dihydrotestosterone and synthesis of sebaceous lipids is regulated by the peroxisome proliferators-activated receptor ligand linoleic acid in human sebocytes. Brit J Dermatol , in press

37 Asada Y, Sonoda T, Ojiro M, Kurata S, Sato T, Ezaki T, Takayasu S: 5alphareductase type 2 is constitutively expressed in the dermal papilla and connective tissue sheath of the hair follicle in vivo but not during culture in vitro. J Clin Endocrinol Metab 2001; 86: 2875-2880

38 Sawaya ME, Shalita AR: Androgen receptor polymorphisms (CAG repeat lengths) in androgenetic alopecia, hirsutism, and acne. J Cutan Med Surg 1998; 3: 9-15

39 Paus R: The biology of hair follicles. N Engl J Med 1999; 341: 491-497

40 Ando Y, Yamaguchi Y, Hamada K, Yoshikawa K, Itami S: Expression of mRNA for androgen receptor, 5alpha-reductase and 17betahydroxysteroid dehydrogenase in human dermal papilla cells. Brit J Dermatol 1999; 141: 840-845

41 Winiarska A, Mandt N, Kamp H, Hossini A, Seltmann H, Zouboulis CC, Blume-Peytavi U: Effect of 5alpha-dihydrotestosterone and testosterone on apoptosis in human dermal papilla cells. Skin Pharmacol Physiol 2006; 19: 311-321

42 Serafini P, Ablan F, Lobo RA: 5alpha-Reductase activity in the genital skin of hirsute women. J Clin Endocrinol Metab 1985; 60: 349-355

43 Randall VA, Thornton MJ, Hamada K, Messenger AG: Mechanism of androgen action in cultured dermal papilla cells derived from human hair follicles with varying responses to androgens in vivo. J Invest Dermatol 1992; 98: 86S-91S

44 Kaufman KD, Dawber RP: Finasteride, a type 2 5alpha-reductase inhibitor, in the treatment of men with androgenetic alopecia. Expert Opin Investig Drugs 1999; 8: 403-415

45 Chen W, Tsai S-J, Liao C-Y, Tsai R-Y, Chen Y-R, Pan B-J, Hung C-L, Zouboulis $C C$ : Higher levels of steroidogenic acute regulatory protein and type I $3 \beta$-hydroxysteroid dehydrogenase in the scalp of men with androgenetic alopecia. J Invest Dermatol 2006; 126: 2332-2335
46 Kim SS, Rosenfield RL: Hyperhydrosis as the only manifestation of hyperandrogenism in an adolescent girl. Arch Dermatol 2000; 136: 430-431

47 Kurata S, Itami S, Komada S, Takayasu S: Intranuclear androgen and cytosolic receptor concentrations in the axillary skin of osmidrosis. Arch Dermatol Res 1990; 282: 33-37

48 Sato T, Sonoda T, Itami S, Takayasu S: Predominance of type I 5alphareductase in apocrine sweat glands of patients with excessive or abnormal odour derived from apocrine sweat (osmidrosis). Br J Dermatol 1998; 139: 806-810

49 Kao JS, Garg A, Mao-Qiang M: Testosterone perturbs epidermal permeability barrier homeostasis. J Invest Dermatol 2001; 116: 443-451

50 Ashcroft G, Mills S: Androgen receptor-mediated inhibition of cutaneous wound healing. J Clin Invest 2002; 110: 615-624

51 Gilliver SC, Ashworth JJ, Mills SJ, Hardman MJ, Ashcroft GS: Androgens modulate the inflammatory response during acute wound healing. J Cell Sci 2006; 119: 722-732

52 Fimmel S, Zouboulis CC: Influence of physiological androgen levels on wound healing and immune status in men. Aging Male 2005; 8: 166-174

53 Lucky AW: A review of infantile and pediatric acne. Dermatology 1998; 196: 95-97

54 New MI: An update of congenital adrenal hyperplasia. Ann N Y Acad Sci 2004: 1038: 14-43

55 Imperato-McGinley J: 5alpha-reductase-2 deficiency and complete androgen insensitivity: lessons from nature. Adv Exp Med Biol 2002; 511: $121-131$

56 Eklof AC, Thurelius AM, Garle M, Rane A, Sjoqvist F: The anti-doping hot-line, a means to capture the abuse of doping agents in the Swedish society and a new service function in clinical pharmacology. Eur J Clin Pharmacol 2003; 59: 571-577

57 Cappel M, Mauger D, Thiboutot D: Correlation between serum levels of insulin-like growth factor 1, dehydroepiandrosterone sulfate, and dihydrotestosterone and acne lesion counts in adult women. Arch Dermatol 2005; 141: 333-338

58 Guy R, Ridden C, Kealey T: The improved organ maintenance of the human sebaceous gland: modeling in vitro the effects of epidermal growth factor, androgens, estrogens, 13-cis retinoic acid, and phenol red. J Invest Dermatol 1996; 106: 454-460

59 Deplewski D, Liao S, Rosenfield RL: Preputial sebocyte 5alpha-reductase isoform specificity. Endocrinology 1997; 138: 4416-4420

60 Rosenfield RL, Deplewski D, Kentsis A, Ciletti N: Mechanisms of androgen induction of sebocyte differentiation. Dermatology 1998; 196 : 43-46

61 Zouboulis CC, Seltmann H, Neitzel H, Orfanos CE: Establishment and characterization of an immortalized human sebaceous gland cell line (SZ95). J Invest Dermatol 1999; 113: 1011-1020

62 Zouboulis CC, Piquero-Martin J: Update and future of systemic acne treatment. Dermatology 2003; 206: 37-53

63 van Vloten WA, Sigurdsson V: Selecting an oral contraceptive agent for the treatment of acne in women. Am J Clin Dermatol 2004; 5 : 435-441

64 Thiboutot DM, Knaggs H, Gilliland K, Hagari S: Activity of type 15 alpha-reductase is greater in the follicular infrainfundibulum compared with the epidermis. Brit J Dermatol 1997; 136: 166-171

65 Carmina E, Godwin AJ, Stanczyk FZ, Lippman JS, Lobo RA: The association of serum androsterone glucuronide with inflammatory lesions in women with adult acne. J Endocrinol Invest 2002; 25: 765-768

66 Zouboulis CC, Seltmann H, Hiroi N, Chen W, Young M, Oeff $M$, Scherbaum WA, Orfanos CE, McCann SM, Bornstein SR: Corticotropinreleasing hormone: an autocrine hormone that promotes lipogenesis in human sebocytes. Proc Nat Acad Sci USA 2002; 99: 7148-7153

67 Baillie AH, Thomson J, Milne JA: The distribution of hydroxysteroid dehydrogenase in human sebaceous glands. $\mathrm{Br} J$ Dermatol 1966; 78 : 451-457

68 Billich A, Meingassner JG, Nussbaumer P, Desrayaud S, Lam C, Winiski A, Schreiner E: 6-[2-(adamantylidene)-hydroxybenzoxazole]-O-sulfamate, a steroid sulfatase inhibitor for the treatment of androgenand estrogen-dependent diseases. J Steroid Biochem Mol Biol 2004; 92: 29-37

69 Thiboutot D, Harris G, Iles V, Cimis G, Gilliland $K$, Hagari S: Activity of the type 15 alpha-reductase exhibits regional differences in isolated sebaceous glands and whole skin. J Invest Dermatol 1995; 105: 209-214

70 Thiboutot D, Gilliland K, Light J, Lookingbill D: Androgen metabolism in sebaceous glands from subjects with and without acne. Arch Dermatol 1999; 135: 1041-1045 
71 Leyden J, Bergfeld W, Drake L, Dunlap F, Goldman MP, Gottlieb AB, Heffernan MP, Hickman JG, Hordinsky M, Jarrett M, Kang S, Lucky A, Peck G, Phillips T, Rapaport M, Roberts J, Savin R, Sawaya ME, Shalita A, Shavin J, Shaw JC, Stein L, Stewart D, Strauss J, Swinehart J, Swinyer $L$, Thiboutot D, Washenik K, Weinstein G, Whiting D, Pappas F, Sanchez $M$, Terranella L, Waldstreicher J: A systemic type I 5 alpha-reductase inhibitor is ineffective in the treatment of acne vulgaris. J Am Acad Dermatol 2004; 50: 443-447

72 Thiboutot D, Bayne E, Thorne J, Gilliland K, Flanagan J, Shao Q Light $\mathrm{J}$, Helm K: Immunolocalization of 5alpha-reductase isozymes in acne lesions and normal skin. Arch Dermaol 2000; 136: 1125-1129

73 Mindnich R, Moller G, Adamski J: The role of 17 beta-hydroxysteroid dehydrogenases. Mol Cell Endocrinol 2004; 218: 7-20

74 Orfanos CE, Adler YD, Zouboulis CC: The SAHA syndrome. Horm Res 2000; 54: 251-258

75 Adler YD, Orfanos CE, Zouboulis CC: HAIRAN syndrome: a fifth variant of SAHA syndrome (abstract). Horm Res 2000; 53: 94

76 Speiser PW, White PC: Congenital adrenal hyperplasia. New Engl J Med 2003; 349: 776-788

77 Huang $N$, Pandey AV, Agrawal V, Reardon W, Lapunzina PD, Mowat D, Jabs EW, Van Vliet G, Sack J, Fluck CE, Miller WL: Diversity and function of mutations in p450 oxidoreductase in patients with AntleyBixler syndrome and disordered steroidogenesis. Am J Hum Genet 2005; 76: 729-749

78 Ramsay B, Alaghband Zadeh J, Carter G, Wheeler MJ, Cream JJ: Raised serum 11-deoxycortisol in men with persistent acne vulgaris. Clin Endocrinol Oxf 1995; 43: 305-310

79 Jabbour SA: . Am J Clin Dermatol 2003; 4: 315-331

80 Zouboulis CC: Therapie der Akne mit Antiandrogenen - Eine evidenzbasierte Übersicht. J Dtsch Dermatol Ges 2003; 1: 535-546

81 Sitruk-Ware R: Pharmacology of different progestogens: the special case of drospirenone. Climacteric 2005; 8 (Suppl 3): 4-12

82 Degitz K, Placzek M, Arnold B, Schmidt H, Plewig G: Congenital adrenal hyperplasia and acne in male patients. Brit J Dermatol 2003; 148: 1263-1266

83 Zouboulis CC: Moderne Aknetherapie. Akt Dermatol 2003; 29: 49-57

84 Thornton MJ: The biological actions of estrogens on skin. Exp Dermatol 2002; 11: 487-502

85 Thornton MJ: Oestrogen functions in skin and skin appendages. Expert Opin Ther Targets 2005; 9: 617-629

86 Brincat MP: Hormone replacement therapy and the skin. Maturitas 2000; 29: 107-117

87 Sator PG, Schmidt JB, Rabe T, Zouboulis CC: Skin aging and sex hormones in women - clinical perspectives for intervention by hormone replacement therapy. Exp Dermatol 2004; 13 (Suppl 4): 36-40

88 Shah MG, Maibach HI: Estrogen and skin. An overview Am J Clin Dermatol 2001; 2: 143-150

89 Brincat M, Versi E, Moniz CF, Magos A, De Trafford J, Studd JW: Skin collagen changes in postmenopausal women receiving different regimens of estrogen therapy. Obstet Gynecol 1987; 70: 123-127

90 Varila E, Rantala I, Oikarinen A, Risteli J, Reunala T, Oksanen H, Punnonen $R$ : The effect of topical estradiol on skin collagen of postmenopausal women. Br J Obstet Gynaecol 1995; 102: 985-989

91 Sumino H, Ichikawa S, Abe M, Endo Y, Ishikawa O, Kurabayashi M: Effects of aging, menopause, and hormone replacement therapy on forearm skin elasticity in women. J Am Geriatr Soc 2004; 52: 945-949

92 Ashcroft Gs, Ashworth JJ: Potential role of estrogens in wound healing. Am J Clin Dermatol 2003; 4: 737-743

93 Boyd AS, Morris LF, Phillips CM, Menter MA: Psoriasis and pregnancy: hormone and immune system interaction. Int J Dermatol 1996; 35: 169-172

94 Raychaudhuri SP, Navare T, Gross J, Raychaudhuri SK: Clinical course of psoriasis during pregnancy. Int J Dermatol 2003; 42: 518-520

95 Dunna SF, Finlay AY: Psoriasis: improvement during and worsening after pregnancy. Br J Dermatol 1989; 120: 584

96 Weinstock MA: Epidemiologic investigation of non melanoma skin cancer mortality: the Rhode Island Follow-Back Study. J Invest Dermatol 1994; 102: 6S-9S

97 Miller JG, Mac Neil S: Gender and cutaneous melanoma. Br J Dermatol 1997; 136: 657-665

98 Hasselquist MB, Goldberg N, Schroeter A, Spelsberg TC: Isolation and characterisation of the estrogen receptor in human skin. J Clin Endocrinol Metab 1980; 50: 76-82

99 Punnonen R, Lovgrent T, Kouvonen I: Demonstration of estrogen receptors in the skin. J Endocrinol Invest 1980; 3: 217-221

100 Gustafsson JA: An update on estrogen receptors. Semin Perinatol 2000; 24: 66-69
101 Kuiper GG, Carlsson B, Grandien K, Enmark E, Haggblad J, Nilsson S, Gustafsson JA: Comparison of the ligand binding specificity and transcript tissue distribution of estrogen receptors $\alpha$ and $\beta$. Endocrinol 1997; 138: 863-870

102 Levin ER: Cellular functions of plasma membrane estrogen receptors. Steroids 2002; 67: 471-475

103 Nadal A, Ropero AB, Fuentes E, Soria B: The plasma membrane estrogen receptor: nuclear or unclear? Trends Pharm Sci 2001; 22: 597-599

104 Aronica SM, Kraus WL, Katzenellenbogen BS: Estrogen action via the CAMP signaling pathway: stimulation of adenylate cyclase and cAMP-regulated gene transcription. Proc Natl Acad Sci USA 1994; 91: 8517-8521

105 Shaul PW: Rapid activation of endothelial nitric oxide synthase by estrogen. Steroids 1999; 64: 28-34

106 Pappas TC, Gametchu B, Watson CS: Membrane estrogen receptors identified by multiple antibody labelling and impeded-ligand binding. FASEB J 1995; 9: 404-410

107 Razandi M, Pedram A, Greene GL, Levin ER: Cell membrane and nuclear estrogen receptors (ERs) originate from a single transcript: studies of ERalpha and ERbeta expressed in Chinese hamster ovary cells. Mol Endocrinol 1999; 13: 307-319

108 Benten WPM, Stephan C, Lieberherr M, Wunderlich F: Estradiol signalling via sequestrable surface receptors. Endocrinol 2001; 142: 1669-1677

109 Saji S, Hirose M, Toi M: Clinical significance of estrogen receptor beta in breast cancer. Cancer Chemother Pharmacol 2005; 56 (Suppl 1): 21-26

110 Mosselman S, Polman J, Dijkema R: ER $\beta$. Identification and characterisation of a novel human estrogen receptor. FEBS Lett 1996; 392: 49-53

111 Thornton MJ, Taylor AH, Mulligan K, Al-Azzawi F, Lyon CC, O'Driscoll JB, Messenger AG: Estrogen receptor beta $(\mathrm{ER} \beta)$ is the predominant estrogen receptor in human scalp. Exp Dermatol 2003; 12: 181-190

112 Thornton MJ, Taylor AH, Mulligan K, Al-Azzawi F, Lyon CC, O'Driscoll $J B$, Messenger AG: The distribution of estrogen receptor beta $(\operatorname{ER} \beta)$ is distinct to that of ER alpha and the androgen receptor in human skin and the pilosebaceous unit. J Investig Dermatol Symp Proc 2003; 8: 100-103

113 Brandenberger AW, Tee MK, Lee JY, Chao V, Jaffe RB: Tissue distribution of estrogen receptors alpha (ER-alpha) and beta (ER-beta) mRNA in the midgestational human fetus. J Clin Endocrinol Metab 1997; 82: 3509-3512

114 Kanda N, Watanabe S: 17beta-estradiol inhibits the production of interferon-induced protein of $10 \mathrm{kDa}$ by human keratinocytes. J Invest Dermatol 2003; 120: 411-419

115 Kanda N, Watanabe S: 17beta-estradiol inhibits the production of RANTES in human keratinocytes. J Invest Dermatol 2003; 120: 420-427

116 Verdier-Sevrain S, Yaar M, Cantatore J, Traish A, Gilchrest BA: Estradiol induces proliferation of keratinocytes via a receptor mediated mechanism. FASEB J 2004; 18: 1252-1254

117 Berthois Y, Katzenellenbogen JA, Katzenellenbogen BS: Phenol red in tissue culture media is a weak estrogen: implications concerning the study of estrogen-responsive cells in culture. Proc Natl Acad Sci USA 1986; 83: 2496-2500

118 Kanda N, Watanabe S: 17beta-estradiol stimulates the growth of human keratinocytes by inducing cyclin D2 expression. J Invest Dermatol 2004; 123: 319-328

119 Haczynski J, Tarkowski R, Jarzabek K, Slomczynska M, Wolczynski S, Magoffin DA, Jakowicki J, Jakimiuk AJ: Human cultured skin fibroblasts express estrogen receptor alpha and beta. Int J Mol Med 2002; 10: $149-153$

120 Haczynski J, Tarkowski R, Jarzabek K, Wolczynski S, Magoffin DA, Czarnocki KJ, Ziegert M, Jakowicki J, Jakimiuk AJ: Differential effects of estradiol, raloxifene and tamoxifen on estrogen receptor expression in cultured human skin fibroblasts. Int J Mol Med 2004; 13: 903-908

121 Conrad F, Paus R: strogene und der Haarfollikel. J Dtsch Dermatol Ges 2004; 2: 412-423

122 Chanda S, Robinette CL, Couse JF, Smart RC: 17beta-estradiol and ICI182780 regulate the hair follicle cycle in mice through an estrogen receptor-alpha pathway. Am J Physiol Endocrinol Metab 2000; 278: E202-E210

123 Ohnemus U, Uenalan M, Conrad F, Handjiski B, Mecklenburg L, Nakamura M, Inzunza J, Gustafsson JA, Paus R: Hair cycle control by estrogens: Catagen induction via ER(alpha) is checked by ER(beta) signalling. Endocrinology 2005; 145: 1214-1225

124 Conrad F, Ohnemus U, Bodo E, Biro T, Tychsen B, Gerstmayer B, Bosio A, Schmidt-Rose T, Altgilbers S, Bettermann A, Saathoff M, Meyer W, Paus R: Substantial sex-dependent differences in the response of human scalp hair follicles to estrogen stimulation in vitro advocate 
gender-tailored management of female versus male pattern balding. J Invest Dermatol Symp Proc 2005; 10: 243-246

125 Sansone-Bazzano G, Reisner RM, Bazzano G: A possible mechanism of action of estrogen at the cellular level in a model sebaceous gland. J Invest Dermatol 1972; 59: 299-304

126 Mesquita-Guimaraes J, Coimbra A: The effect of sexual hormones on the lipid and proteinaceous secretion of the rat preputial sebaceous gland. Arch Dermatol Res 1981; 270: 325-331

127 Plewig G, Kligman AM: Acne and Rosacea 3rd ed. Berlin: Springer, 2003

128 Kariya Y, Moriya T, Suzuki T, Chiba M, Ishida K, Takeyama J, Endoh M, Watanabe M, Sasano H: Sex steroid hormone receptors in human skin appendage and its neoplasms. Endocr J 2005; 52: 317-325

129 Beier K, Ginez I, Schaller H: Localization of steroid hormone receptors in the apocrine sweat glands of the human axilla. Histochem Cell Biol 2005; 123: 61-65

130 Simpson ER, Zhao Y, Agarwal VR et al: Aromatase expression in health and disease. Recent Prog Horm Res 1997; 52: 185-213

131 Simpson ER: Role of aromatase in sex steroid action. J Mol Endocrinol 2000; 25: 149-156

132 Harada N: A new aspect of the pharmacological and physiological significance of the aromatase/estrogen system. (in Japanese) Nippon Yakurigaku Zasshi - Folia Pharmacologica Japonica 1998; 112: 51-58

133 Harada N: Aromatase and intracrinology of estrogen in hormonedependent tumors. Oncology 1999; 57 (Suppl 2): 7-16

134 Sawaya ME, Price VH: Different levels of 5alpha-reductase type I and II, aromatase, and androgen receptor in hair follicles of women and men with androgenetic alopecia. J Invest Dermatol 1997; 109: 296-300

135 Hoffmann R, Niiyama S, Huth A, Kissling S, Happle R: 17alpha-estradiol induces aromatase activity in intact human anagen hair follicles ex vivo. Exp Dermatol 2002; 11: 376-380

136 Hughes SV, Robinson E, Bland R, Lewis HM, Stewart PM, Hewison M: 1,25-dihydroxyvitamin D3 regulates estrogen metabolism in cultured keratinocytes. Endocrinology 1997; 138: 3711-3718

137 Svenstrup B, Brunner N, Dombernowsky P, Nohr I, Micic S, Bennett P, SpangThomsen M: Comparison of the effect of cortisol on aromatase activity and androgen metabolism in two human fibroblast cell lines derived from the same individual. J Steroid Biochem 1990; 35: 679-687

138 Rink JD, Simpson ER, Barnard JJ, Bulun SE: Cellular characterization of adipose tissue from various body sites of women. J Clin Endocrinol Metab 1996; 81: 2443-2447

139 Kroumpouzos G, Cohen LM: Dermatoses of pregnancy. J Am Acad Dermatol 2001; 45: 1-19

140 Wade TR, Wade SL, Jones HE: Skin changes and diseases associated with pregnancy. Obstet Gynecol 1978; 52: 233-242

141 Beas F, Vargas L, Spada RP, Merchak N: Pseudoprecocious puberty in infants caused by a dermal ointment containing estrogens. J Pediatr 1969; 75: 127-130

142 Taylor AH, Thornton MJ, Messenger AG, Tobin DJ: Human epidermal melanocytes express the androgen receptor and both estrogen receptors (ER $\alpha$ ) and (ER $\beta)$ in situ. J Invest Dermatol 2002; 119: 801

143 Jee SH, Lee SY, Chiu HC, Chang CC, Chen TY: Effects of estrogen and estrogen receptor in normal human melanocytes. Biochem Biophys Res Commun 1994; 199: 1407-1412

144 Im S, Lee ES, Kim W, On W, Kim J, Lee M, Kang WH: Donor specific response of estrogen and progesterone on cultured human melanocytes. J Korean Med Sci 2002; 17: 58-64

145 Meskiri AN, Thornton MJ, Tobin DJ: Expression of estrogen receptors in cutaneous melanocytes and their potential role in the regulation of pigment cell phenotype. In: Trüeb RM (ed) Understanding Hair Biology European Hair Research Society, 11th Meeting, Zurich, Dermatology 2005; 211(special issue 1)

146 Meskiri AN, Thornton MJ, Tobin DJ Induction of pigmentation up regulates ERalpha and aromatase in epidermal melanocytes and melanoma cells http:/www.endocrine-abstracts.org 196th Meeting of the Society for Endocrinology, London, UK 7-9 November 2005, Endocrine Abstracts 2005; 10: 78

147 Schleicher RL, Hitselberger MH, Beattie CW: Inhibition of hamster melanoma growth by estrogen. Cancer Res 1987; 47: 453-459

148 Hitselberger MH, Schleicher RL, Beattie CW: Effects of estradiol on estrogen receptor, progesterone receptor, and tyrosinase in hamster melanoma transplanted into athymic mice. Cancer Res 1988; 48: 3720-3727

149 Feucht KA, Walker MJ, Das Gupta TK, Beattie CW: Effect of 17 beta-estradiol on the growth of estrogen receptor-positive human melanoma in vitro and in athymic mice. Cancer Res 1988; 48: 7093-7101

150 Armstrong LE, Maresh CM, Keith NR, Elliott TA, Vanheest JL, Scheett TP, Stoppani J, Judelson DA, De Souza MJ: Heat acclimation and physical training adaptations of young women using different contraceptive hormones. Am J Physiol Endocrinol Metab 2005; 288: E868-E875
151 Houghton BL, Holowatz LA, Minson CT: Influence of progestin bioactivity on cutaneous vascular responses to passive heating. Med Sci Sports Exerc 2005; 37: 45-51; discussion 2

152 Landau RL, Bergenstal DM, Lugibihl K, Kascht ME: The metabolic effects of progesterone in man. J Clin Endocrinol Metab 1955; 15: 1194-1215

153 Kagawa CM, Cella JA, Van Arman CG: Action of new steroids in blocking effects of aldosterone and desoxycorticosterone on salt. Science 1957; 126: 1015-1016

154 Edgren RA, Elton RL: Estrogen antagonisms: effects of several steroidal spironolactones on estrogen-induced uterine growth in mice. Proc Soc Exp Biol Med 1960; 104: 664-665

155 Neumann F: Intersexuality of male foetuses and inhibition of androgenic function in adult animals with a testosterone blocker. Ger Med Month 1967; 12: 182-188

156 Cumming DC, Yang JC, Rebar RW, Yen SS: Treatment of hirsutism with spironolactone. JAMA 1982; 247: 1295-1298

157 Drill VA: Endocrine properties and long-term safety of oral contraceptives. Metabolism 1965; 14 (Suppl): 295-310

158 Forman B, Samuels $H$ : Interactions among a subfamily of nuclear hormone receptors: the regulatory zipper model. Mol Endocrinol 1990; 4: 1293-1301

159 Chang CS, Kokontis J, Liao ST: Structural analysis of complementary DNA and amino acid sequences of human and rat androgen receptors. Proc Natl Acad Sci USA 1988; 85: 7211-7215

160 de Gooyer ME, Deckers GH, Schoonen WG, Verheul HA, Kloosterboer $H J$ : Receptor profiling and endocrine interactions of tibolone. Steroids 2003; 68: 21-30

$161 \mathrm{Liu} \mathrm{JH}$ : Therapeutic effects of progestins, androgens, and tibolone for menopausal symptoms. Am J Med 2005; 118: 88-92

162 Mauvais-Jarvis P, Kuttenn F, Baudot N: Inhibition of testosterone conversion to dihydrotestosterone in men treated percutaneously by progesterone. J Clin Endocrinol Metab 1974; 38: 142-147

163 Juchem M, Pollow K, Elger W, Hoffmann G, Mobus V: Receptor binding of norgestimate - a new orally active synthetic progestational compound. Contraception 1993; 47: 283-294

164 Wiegratz I, Kuhl H: Progestogen therapies: differences in clinical effects? Trends Endocrinol Metab 2004; 15: 277-285

165 Sitruk-Ware R: Pharmacological profile of progestins. Maturitas 2004; 47: 277-283

166 Thomas CP, Liu KZ, Vats HS: Medroxyprogesterone acetate binds the glucocorticoid receptor to stimulate (alpha)-ENaC and sgk1 expression in renal collecting duct epithelia. Am J Physiol Renal Physiol 2006; 290: F306-F312

167 Stachenfeld NS, Silva C, Keefe DL, Kokoszka CA, Nadel ER: Effects of oral contraceptives on body fluid regulation. J Appl Physiol 1999; 87: 1016-1025

168 Suzuki T, Nakamura Y, Moriya T, Sasano H: Effects of steroid hormones on vascular functions. Microsc Res Tech 2003; 60: 76-84

169 Perusquia M, Villalon CM, Navarrete E, Garcia GA, Perez-Palacios G, Lemus $A E$ : Vasodilating effect of norethisterone and its 5 alpha metabolites: a novel nongenomic action. Eur J Pharmacol 2003; 475: 161-169

170 Dumont M, Luu-The V, Dupont E, Pelletier G, Labrie F: Characterization, expression, and immunohistochemical localization of 3 betahydroxysteroid dehydrogenase/delta 5-delta 4 isomerase in human skin. J Invest Dermatol 1992; 99: 415-421

171 Pelletier G, Ren L: Localization of sex steroid receptors in human skin. Histol Histopathol 2004; 19: 629-636

172 Thody AJ, Shuster S: Effect of progesterone on the sebaceous glands. Postgrad Med J 1978; 54 (Suppl 2): 88-90

173 Girard J, Barbier A, Lafille C: Inhibition of testosterone metabolism and lipogenesis in animal sebaceous glands by progesterone. Arch Dermatol Res 1980; 269: 281-290

174 Kanda N, Watanabe S: Regulatory roles of sex hormones in cutaneous biology and immunology. J Dermatol Sci 2005; 38: 1-7

175 Rosenfield RL: Clinical practice. Hirsutism. N Engl J Med 2005; 353 : 2578-2588

176 Arowojolu AO, Gallo MF, Grimes DA, Garner SE: Combined oral contraceptive pills for treatment of acne. Cochrane Database Syst Rev 2004;CD004425

177 Thorneycroft H, Gollnick H, Schellschmidt I: Superiority of a combined contraceptive containing drospirenone to a triphasic preparation containing norgestimate in acne treatment. Cutis 2004; 74: 123-130

178 Cormia FE: Alopecia from oral contraceptives. JAMA 1967; 201: 635-637

179 Ross EK, Shapiro J: Management of hair loss. Dermatol Clin 2005; 23 . 227-243

180 Freedman RR: Hot flashes: behavioral treatments, mechanisms, and relation to sleep. Am J Med 2005; 118: 124-130 